\title{
Wernicke encephalopathy
}

SWI detects petechial hemorrhages in mammillary bodies in vivo

Figure 1 Susceptibility-weighted imaging (SWI) detects microbleeds in the mammillary bodies as a hallmark of Wernicke encephalopathy (WE)

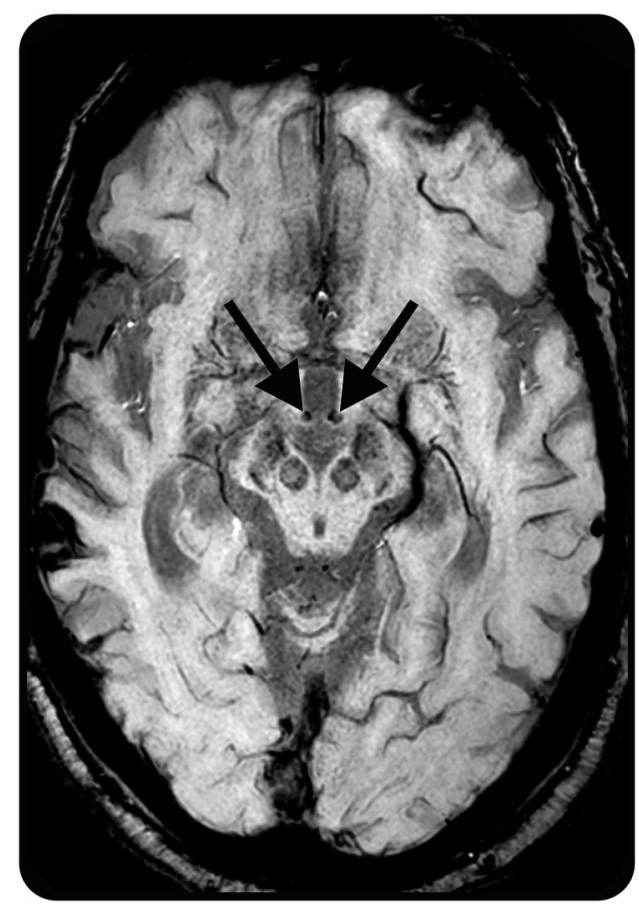

Axial SWI of an alcoholic patient with ataxia, nystagmus, and disorientation due to acute WE shows 2 dark spots in the mammillary bodies, indicating microbleeds in this brain region.

In 1881, Carl Wernicke ${ }^{1}$ described a "polioencephalopathia haemorrhagica superior" in 3 alcoholic patients with gray matter hemorrhages in the mammillary bodies.

Contrast enhancement in the mammillary bodies, an important imaging sign of Wernicke encephalopathy (WE), suggests a disrupted blood-brain barrier, which may be the cause for the microbleeds.

In a 58-year-old man with acute WE, brain magnetic resonance susceptibility-weighted imaging (SWI) revealed blood deposits in mammillary bodies, which were not evident on standard T2* images (figures 1 and 2). SWI may be a preferred sequence to detect the pathologic hallmark of WE in vivo and extends the MRI characteristics of this treatable condition. ${ }^{2}$

Elke Hattingen, MD, PhD, Aline Beyle, MD, Andreas Müller, MD, Thomas Klockgether, MD, PhD, Cornelia Kornblum, MD, PhD

From the University Hospital of Bonn (E.H., A.B., A.M., T.K., C.K.) and the German Center for Neurodegenerative Diseases (T.K.), Bonn, Germany.

Author contributions: Prof. Dr. Elke Hattingen: discovery of the pathology in this case, interpretation, manuscript writing. Dr. Aline Beyle: acquisition of clinical data, analysis and interpretation. Dr. Andreas Müller: acquisition of the magnetic resonance data, analysis and interpretation. Prof. Dr. Thomas Klockgether: critical revision of the manuscript for important intellectual content. Prof. Dr. Cornelia Kornblum: critical revision of the manuscript for important intellectual content.

Study funding: No targeted funding reported.

Disclosure: E. Hattingen is a consultant for the Fraunhofer Institut Frankfurt. A. Beyle and A. Müller report no disclosures relevant to the manuscript. T. Klockgether receives/has received research support from the Deutsche Forschungsgemeinschaft (DFG), the Bundesministerium für Bildung und Forschung (BMBF), the Robert Bosch Foundation, and the European Union (EU). He serves on 


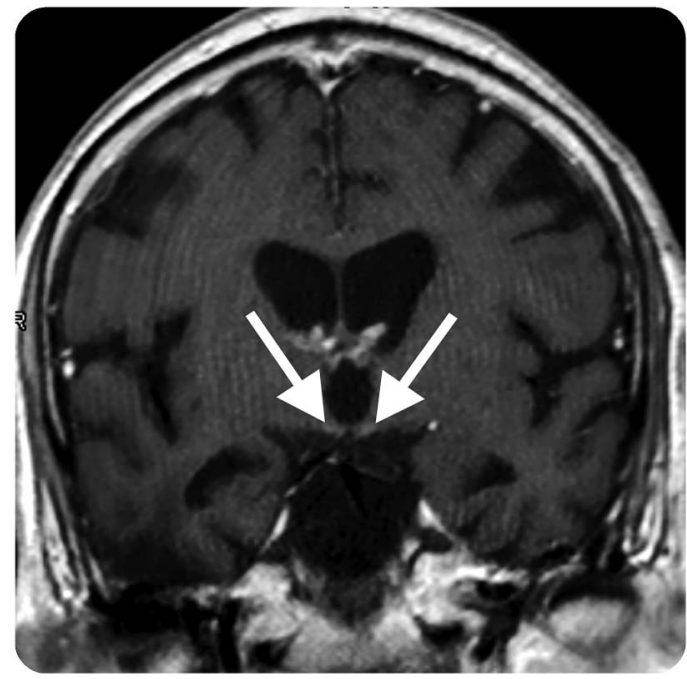

Coronal T1-weighted image after application of contrast agent shows a faint enhancement in the mammillary bodies.

the editorial board of The Cerebellum and the Journal of Neurology. He has received consulting fees from ICON Clinical Research and Atheneum. C. Kornblum has received travel grants and speakers honoraria from Sanofi-Genzyme and funding from the German Ministry of Education and Research (BMBF: 01GM0862), the Deutsche Gesellschaft für Muskelkranke e.V. (Me4/1), and the Marigold Foundation, Canada. Go to Neurology.org for full disclosures.

Correspondence to Dr. Hattingen: elke.hattingen@ukb.uni-bonn.de

1. Wernicke C. Die acute, hämorrhagische Poliencephalitis superior. In: Wernicke C, ed. Lehrbuch der Gehirnkrankheiten für Aerzte und Studirende, 2nd ed. Berlin: Verlag von Theodor Fischer; 1881:229-242.

2. Cerejo R, Newey C, Stillman M. Teaching NeuroImages: Wernicke encephalopathy: diagnostically deceptive but treatable. Neurology 2013;80:e92.

\section{Translate Today's Discoveries into Tomorrow's Clinic at 2017 Breakthroughs in Neurology Conference}

Get a year-in-review of the latest science and education while earning up to $27 \mathrm{CME}$-with 11.25 qualifying for self-assessment CME—at the 2017 Breakthroughs in Neurology Conference, set for January 13-16 at the beautiful Sheraton Grand at Wild Horse Pass. Secure your spot today: AAN.com/view/breakthroughs.

\section{Complimentary CME and Self-assessment Resources: An Exclusive AAN Membership Benefit!}

Looking for ways to earn important CME credits in 2016? Look no further, because AAN membership provides FREE* access to the AAN's suite of online learning programs: NeuroSAE ${ }^{\circledR}$, NeuroLearn $^{\mathrm{SM}}$, and NeuroPI ${ }^{\mathrm{SM}}$. Access from virtually anywhere-home or office-to meet your CME needs, as well as take the necessary steps toward fulfilling your maintenance of certification (MOC) requirements, as mandated by the ABPN. Visit AAN.com/view/MOC today!

*Free access is limited to one course per program at a time. 


\section{Neurology}

\section{Wernicke encephalopathy: SWI detects petechial hemorrhages in mammillary bodies in vivo}

Elke Hattingen, Aline Beyle, Andreas Müller, et al. Neurology 2016;87;1956-1957

DOI 10.1212/WNL.0000000000003294

\section{This information is current as of October 31, 2016}

\section{Updated Information \& Services}

References

Subspecialty Collections

Permissions \& Licensing

Reprints including high resolution figures, can be found at: http://n.neurology.org/content/87/18/1956.full

This article cites 1 articles, 1 of which you can access for free at: http://n.neurology.org/content/87/18/1956.full\#ref-list-1

This article, along with others on similar topics, appears in the following collection(s):

All Clinical Neurology

http://n.neurology.org/cgi/collection/all_clinical_neurology

MRI

http://n.neurology.org/cgi/collection/mri

Nutritional

http://n.neurology.org/cgi/collection/nutritional

Information about reproducing this article in parts (figures,tables) or in its entirety can be found online at:

http://www.neurology.org/about/about_the_journal\#permissions

Information about ordering reprints can be found online:

http://n.neurology.org/subscribers/advertise

Neurology ${ }^{\circledR}$ is the official journal of the American Academy of Neurology. Published continuously since 1951, it is now a weekly with 48 issues per year. Copyright () 2016 American Academy of Neurology. All rights reserved. Print ISSN: 0028-3878. Online ISSN: 1526-632X.

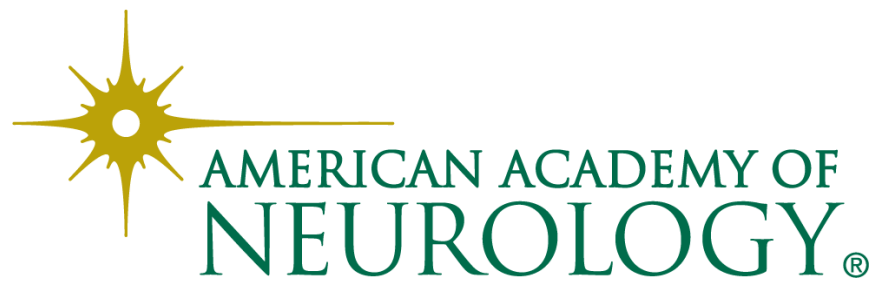

